Review Article

\title{
Composition, Physicochemical Properties, and Uses of Acorn Starch
}

\author{
Mehdi Taib iD and Lahboub Bouyazza \\ Laboratory of Applied Chemistry and Environment, Hassan 1st University Faculty of Science and Technology, P.O. Box 577, \\ Settat, Morocco \\ Correspondence should be addressed to Mehdi Taib; m.taib@uhp.ac.ma
}

Received 15 March 2021; Accepted 14 June 2021; Published 21 June 2021

Academic Editor: Carola Esposito Corcione

Copyright (c) 2021 Mehdi Taib and Lahboub Bouyazza. This is an open access article distributed under the Creative Commons Attribution License, which permits unrestricted use, distribution, and reproduction in any medium, provided the original work is properly cited.

\begin{abstract}
The major component of acorn is starch, which may amount up to 55\% of the dry weight. Lack of systematic knowledge on acorn starch greatly hinders the further development of acorns as sustainable crops. This review aims to summarize the current knowledge of the isolation, chemical composition, physicochemical properties, and uses of acorn starches and to provide future research directions. The amylose content of the acorn starches is reported to vary in the range of 20-39\%. Moisture content, lipid, ash, and protein contents of the acorn starches have been reported varying from 2.20 to $15.50 \%, 0.23$ to $2.64 \%, 0.01$ to $1.41 \%$, and 0.01 to $6.7 \%$, respectively. Thermal and pasting properties that have usually been determined using differential scanning calorimeter (DSC) and rapid viscoanalyzer (RVA) are also discussed in this article. Acorn starch has great potential for various food and nonfood applications due to the unique structural and functional features.
\end{abstract}

\section{Introduction}

Quercus spp. (oaks) represent an important genus of the Fagaceae family which consists of 600 species worldwide, including monoecious, deciduous, evergreen trees, and rarely shrubs [1]. These species produce a widely known fruit, commonly identified as acorns, which are of vital importance for both humans and animals. Acorns are a good source of starch, protein, fat, minerals (such as $\mathrm{P}, \mathrm{K}$, $\mathrm{Ca}$, and $\mathrm{Mg}$ ), unsaturated fatty acids (i.e., oleic acid), and vitamins (mostly $\mathrm{A}$ and $\mathrm{E}$ ) [2-8]. In addition, acorns contain numerous biologically active compounds (such as tannins, phenolic acids, and flavonoids), which are essential in the human diet to maintain an adequate level of antioxidants [2]. In particular, acorn can be a major ingredient of gluten-free food products for people with celiac diseases [9]. Recently, acorns have attracted intensive attention as functional food because of their various biological activities, such as antioxidant, antiinflammation, antibacterial, antitumor, and prevention of degenerative diseases [10-12]. Various food products have been developed from acorn in the light of the abovementioned health impacts. These include bread, pasta, biscuits, hot beverages, cakes, and cookies [9, 13-17]. However, acorn utilization has been mainly limited to traditional uses. The underutilization of acorns in the food industry might be explained by some current consumer trends, but also due to the lack of a number of chemical characterization studies sufficient enough to validate their true potential [2]. There is also the further constraint of their astringency, which, in some cases, might compromise their acceptability as food [18].

Among all the nutrients, starch is the largest component of acorns (about 55\%) (Table 1), providing a potential alternative to traditional starchy raw materials. Acorn starch is rich in resistant starch (RS) fraction $(30.8-41.4 \%)[29,30]$. In recent years, RS has received a lot of attention for both its potential health benefits and functional properties [18]. Recent research has shown that acorn starch can be an ingredient for food and nonfood applications [16, 21, 31]. Compared with other starches from cassava, barley, potato, and wheat, there is a lack of systematic knowledge of acorn 
TABLE 1: Yield and chemical composition of acorn starch.

\begin{tabular}{|c|c|c|c|c|c|c|c|c|}
\hline Genotype & $\begin{array}{c}\text { Starch } \\
\text { yield (\%) }\end{array}$ & $\begin{array}{c}\text { Amylose } \\
\text { content (\%) }\end{array}$ & $\begin{array}{c}\text { Protein } \\
(\%)\end{array}$ & $\begin{array}{c}\text { Moisture } \\
(\%)\end{array}$ & $\begin{array}{l}\text { Ash } \\
(\%)\end{array}$ & $\begin{array}{c}\text { Lipid } \\
(\%)\end{array}$ & $\begin{array}{c}\text { Fiber } \\
(\%)\end{array}$ & Reference \\
\hline Acorn (Quercus suber) & $\begin{array}{l}88.5 \\
86.9 \\
\end{array}$ & nd & nd & nd & nd & nd & nd & Correia et al. [19] \\
\hline $\begin{array}{l}\text { Quercus ilex subsp. ballota } \\
\text { (four varieties) }\end{array}$ & - & $\begin{array}{c}39 \\
20.16 \\
21 \\
20 \\
\end{array}$ & $\begin{array}{l}1.05 \\
0.91 \\
0.01 \\
0.61 \\
\end{array}$ & $\begin{array}{c}2.20 \\
15.90 \\
10.2 \\
12.44\end{array}$ & $\begin{array}{l}0.14 \\
0.18 \\
0.10 \\
0.12 \\
\end{array}$ & $\begin{array}{l}0.63 \\
0.31 \\
0.23 \\
0.41 \\
\end{array}$ & $\begin{array}{l}0.17 \\
0.29 \\
0.01 \\
0.64 \\
\end{array}$ & $\begin{array}{l}\text { Boukhelkhal and Moulai- } \\
\text { Mostefa [20] }\end{array}$ \\
\hline Quercus ilex & 34.5 & nd & 0.92 & 10.17 & 2.66 & 0.51 & nd & Zarroug et al. [21] \\
\hline Quercus suber & nd & 24.44 & nd & 7.22 & 0.13 & nd & nd & $\begin{array}{c}\text { Irinislimane and } \\
\text { Belhaneche-Bensemra [22] }\end{array}$ \\
\hline Quercus leucotrichophora & 54.7 & 15.6 & nd & 15.5 & 1.41 & 2.64 & nd & Soni et al. [23] \\
\hline Quercus acutissima C. & nd & 28.56 & 0.12 & 12.61 & 0.05 & 0.08 & nd & Yoo et al. [24] \\
\hline Quercus branti & nd & 21.15 & nd & nd & nd & nd & nd & Molavi et al. [25] \\
\hline Not specified & nd & nd & nd & 13.40 & nd & nd & nd & Deng et al. [26] \\
\hline Not specified & nd & 19 & nd & nd & nd & nd & nd & Chen et al. [27] \\
\hline Quercus palustris Muenchh. & 17.3 & 31.4. & 6.7 & 37.9 & nd & 4.2 & nd & Stevenson et al. [28] \\
\hline
\end{tabular}

Nd: not determined.

starch. This hinders the efficient development of acorn as sustainable crops.

Therefore, the objective of this review is to summarize the present knowledge on the isolation, chemical composition, granular and physicochemical properties, digestibility, modifications, and applications of acorn starches and to provide future research directions.

\section{Starch Extraction Methods and Yield}

The isolation methods from different reports shared a similar pattern, regardless of the acorn species. Fruits are generally dehulled, chopped, and milled for flour production. The Flour is soaked and wet milled. The chemical or enzyme treatment, screen size, and centrifugal speed have been applied to speed up the isolation of starch from the other compounds such as protein, fat, sugars, and fiber. One of the earliest methods of acorn starch isolation was proposed by [28] which include a treatment with $0.3 \% \mathrm{w} / \mathrm{v}$ sodium metabisulfite solution for steeping, nylon mesh $(106 \mathrm{~mm})$ for screening, and repeated toluene washing $(10 \%$ toluene in $0.1 \mathrm{M}$ aqueous sodium chloride) for removing protein and lipids. The resulting starch was dried in the air at room temperature. The effects of isolation methods on acorn starch were reported in [29]. The best results in terms of purity, yield, and pasting properties were obtained for two methods that applied low shear with protease digestion and low shear with alkali treatment. Molavi et al. [25] outlined a process for acorn starch extraction that was based on a method developed by Correia and Beirão-da-Costa [32]. Acorns are dry milled into flour, and the resulting flour is soaked in $0.25 \% \mathrm{NaOH}$. After this, suspensions were homogenized and screened through a $180 \mathrm{~mm}$ sieve. The precipitate was screened successively in $75 \mathrm{~mm}$ and $53 \mathrm{~mm}$ sieves and centrifuged. Starch extracted using this process has been shown to have high purity and yield along with a less damaged structure. Li et al. [7] described a method of isolation of starch from acorn which included steeping of acorn flour in $0.3 \%$ sodium hydroxide $(1: 5, \mathrm{w} / \mathrm{w})$, screening of the dispersion through a mesh sieve a $0.18 \mathrm{~mm}$, and then purification by centrifugation. It should be noted that the physicochemical properties of acorn starch are more affected by differences in isolation method and experimental conditions [32-34]. The starch yield was in range of 48.93 to $89.83 \%[28,32,35]$. The purity of starch ranged from $98.1 \%$ to $97.6 \%[32]$.

\section{Molecular Structure}

There have been very limited reports on the chemical structures of amylose and amylopectin components from acorn starch. The molecular weight of starch has been shown to range from $2.65 \times 10^{7}$ to $8.22 \times 10^{7} \mathrm{~g} / \mathrm{mol}$ [20]. Furthermore, it was reported that acorn amylopectin molar mass, gyration radius, and density were comparable to other A-type starches [28]. The average branch chain length of amylopectin was DP 25.5. Acorn starch showed a lower percentage of amylopectin (AP) branched short chains (DP 6-12: 28.6\%) and very long chain (DP $>37: 2.3 \%)$ and a higher percentage of AP branched long chains (DP 13-36: 69.1\%) [24].

\section{Chemical Composition}

Starch is a mixture of two biopolymers: amylose and amylopectin. The two polysaccharides are homoglycans with only two types of chain linkages, $\alpha$-(1-4) bonds of the main chain and $\alpha-(1-6)$ bonds in the branching points. The resulting starch showed a wide variation in the chemical composition (Table 1). Amylose content of the acorn starches is reported to vary in the range of approx. $20-39 \%$ (Table 1).The difference in amylose contents of acorn starches could be readily attributed to the differences in acorn genetics, growing conditions of the crop, and methods 
of estimation $[20,36]$. The complexes (amylose-lipid complex or amylose-iodine complex) may also hinder actual estimation of amylose content [37]. The moisture content of starch from different acorn sources has been reported in the range of $7.22-15.91[20,22,23]$. The moisture content is similar to air-equilibrated cereal starches (10-12\%) and some roots and tubers (14-18\%) [36]. Minor components of starch such as lipids, proteins, and ash were also reported (Table 1). The protein contents ranged from 0.01 to $6.7 \%$ [20, 24, 28], lipid from 0.23 to $2.64 \%$ [20, 23], and ash from 0.01 to $1.41 \%[20,22-24]$. The nitrogen content of acorn starch was $0.04 \%$ [25] and phosphorus-containing compounds were found in a small quantity of $0.01 \%$ [23]. Thus, residual lipid content is typically very low in acorn starches and may have a negligible effect on starch functionality.

\section{Granular Structure: Morphology, Polymorphism, and Crystallinity}

The morphology of acorn starch (Figure 1) has been widely analyzed using scanning electron microscopy (SEM) (Table 2). The morphological features of acorn starch including the size and the shape have been summarized (Table 2). The shape of acorn starch was spherical, elliptical, and irregular. The surfaces of starch extracted from acorn have been reported to be smooth with no fissures, suggesting that the extracted starches are relatively pure $[7,20]$. The particle size distribution of acorn starch granules has been also reported in many investigations $[7,20,23,25,28]$. Sizes of acorn starch granules $(3.3-126.2 \mu \mathrm{m})$ were found to be similar to those reported in potato starch $(1-110 \mu \mathrm{m})$ [7]. The size range of $2-24 \mu \mathrm{m}$ was the most frequent (Table 2). The variation observed in the shape and size of granules may be due to extraction and purification methods, environmental conditions, growth stage of plant, and genotype. The morphology of acorn starch granules may be better described and quantified by other techniques such atomic force microscopy and laser-light scattering to probe other structural aspects [39].

In granules, the external chains of amylopectin chains interact with each other and water molecules to form double helices and crystals. The crystals of the granules are arranged systematically to give 3 types of polymorph (A-, B-, and C-types) [40]. The A- and B-type polymorphs are discerned based on the packing arrangement of double helices within amylopectin and their level of hydration [41]. C-type is a mixture of both A- and B-type [40]. The polymorph type of acorn starch has been inconclusive among various reports. Acorn starch was B-type [26, 42]. A-type polymorph was reported for acorn starch [7, 23, 24, 27, 28]. C-type polymorph was also noted $[19,25,33,43]$. The degree of crystallinity of acorn starch ranged between 22.3 and $47.8 \%$ (Table 2). The degree of crystallinity of acorn starch has been reported to be lower than black wheat, buckwheat, coix seed, naked oat, and corn starches and higher than kuzhu, jiaoyu, and longya lily starches [26]. The difference in the diffraction pattern and degree of crystallinity of starch granules was mainly influenced by genotypic, agronomic, and growing conditions (e.g., temperature) $[26,44]$.

\section{Gelatinization Properties}

Starch gelatinization is a physical process, in which the granule breaks and swells when heated in the presence of excess water. This process results in a phase transition of starch granules from an ordered state to a disordered state $[41,45]$. The gelatinization can be measured by various methods with DSC being most used for acorn starch analysis where onset (To), peak (Tp), conclusion (Tc) temperatures, and enthalpy change $(\Delta H)$ are regularly recorded (Table 3 ). The range of gelatinization temperatures in the literature is shown from 55 to $75.2^{\circ} \mathrm{C}$, while the gelatinization enthalpy is found varying from 6.52 to $20.8 \mathrm{~J} / \mathrm{g}$ [20, 25, 28]. Nevertheless, Soni et al. [23] revealed that $\mathrm{Tp}$ of acorn starches ranged from 80 to $85^{\circ} \mathrm{C}$ using polarizing microscope. Hence, methods (DSC vs. polarizing microscope) should be taken into consideration when comparing data from different studies. Different DSC studies used different experimental conditions including starch-to-water ratio $(1: 2$ to $1: 3)$ and scanning rate $(1-10 \mathrm{C} / \mathrm{min})[19,20]$. These factors may have an impact on the thermal parameters of starch gelatinization. Comparative studies showed that the gelatinization temperatures of acorn starches were lower than those of cassava and corn starches and were high than those of chestnut starches $[29,43]$. This differences in gelatinization properties among different starches could be ascribed to the factors like amylose content, crystallinity, and nonstarch content $[36,37]$. The impact of the amylopectin chain length in acorn starch on starch gelatinization rests unclear. Therefore, future studies should be conducted to characterize the amylopectin distribution in acorn starch and determine the effect of the chain length distribution of amylopectin on its physicochemical properties.

\section{Pasting Properties}

Pasting is defined as state which follows gelatinization of starch. The starch paste can be described as a two-phase system consisting of a discontinuous phase of swollen granules and a continuous phase of solubilized amylose and/ or amylopectin [36]. The Brabender viscoamylograph (BVA) and rapid viscoanalyzer (RVA) have been widely applied to examine the pasting characteristics of acorn starches (Table 4). The pasting properties are investigated in terms of pasting temperatures and viscosities, which are characterized as peak, breakdown, setback, and final viscosities. The pasting properties of these starches have been determined at different experimental conditions and different concentrations and by employing different instruments. Hence, it is difficult to make a meaningful comparison of the data shown in Table 4. Peak viscosity, breakdown viscosity, setback viscosity, final viscosity, and pasting temperature of different acorn starches have been reported in the ranges of 183-3338 cP, 54-427 cP, $163-1630 \mathrm{cP}, 260-3654 \mathrm{cP}$, and $70-96^{\circ} \mathrm{C}$, respectively, as shown in Table 4 . The difference in pasting properties of acorn starches is in general attributed to amylose content, amylose leaching, degree of crystallinity, granule size, amylopectin molecular structure, and nonstarch content (e.g., lipids, phosphorus-containing 

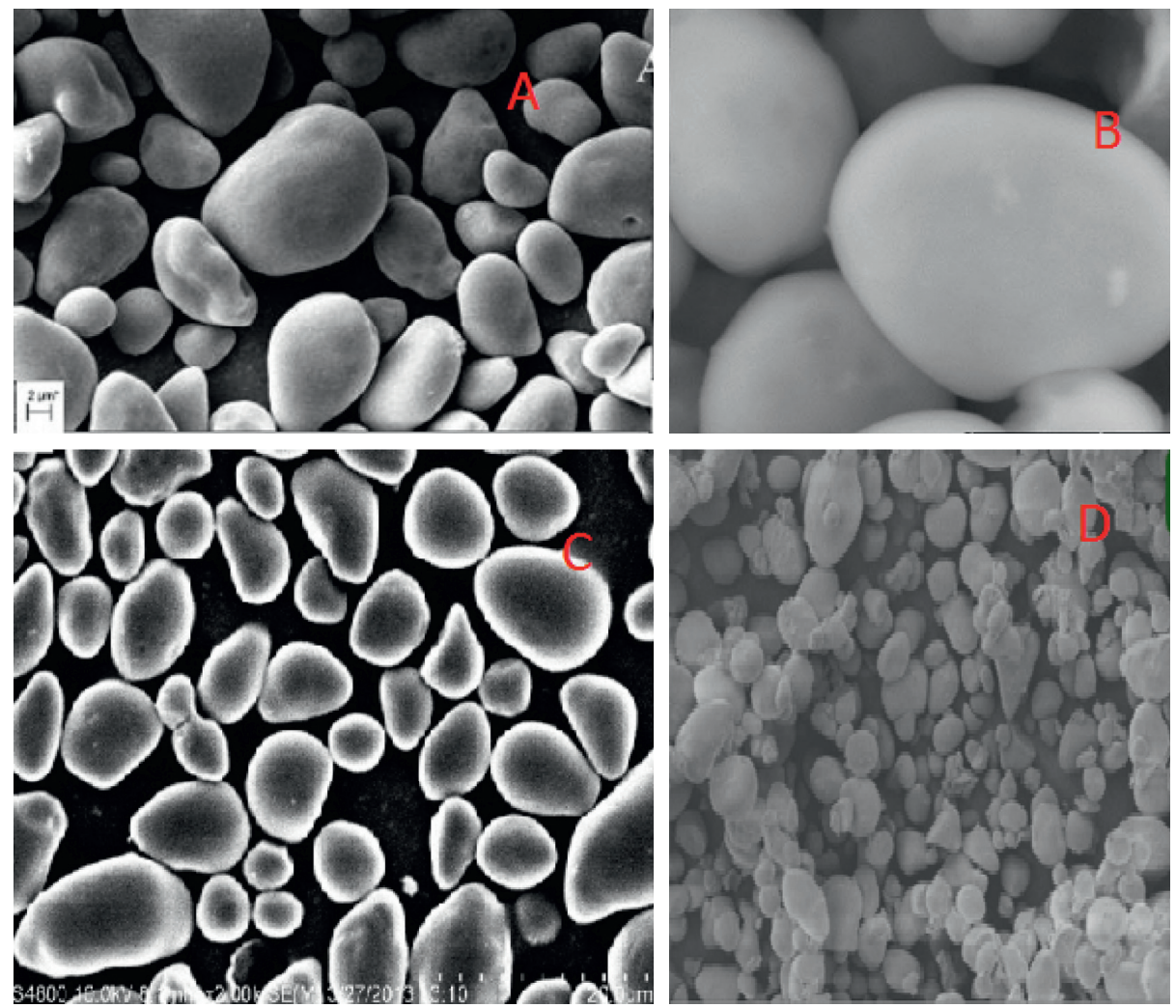

Figure 1: Selected SEM images of acorn starch. (a) Molavi et al. [25]. (b) Boukhelkhal and Moulai-Mostefa [20]. (c) Li et al. [7]. (d) Deng et al. [26].

TABLE 2: Morphology, X-ray diffraction pattern, and degree of crystallinity of acorn starch.

\begin{tabular}{|c|c|c|c|c|c|c|}
\hline Genotype & $\begin{array}{c}\text { Granule } \\
\text { size }(\mu \mathrm{m})\end{array}$ & $\begin{array}{l}\text { Analytical } \\
\text { technique }\end{array}$ & Shape description & $\begin{array}{c}\text { Diffraction } \\
\text { pattern }\end{array}$ & $\begin{array}{c}\text { Degree of } \\
\text { crystallinity (\%) }\end{array}$ & Reference \\
\hline $\begin{array}{l}\text { Quercus ilex subsp. } \\
\text { ballota (four varieties) }\end{array}$ & $2.5-24$ & SEM & $\begin{array}{l}\text { Spherical, ovoid, and } \\
\text { sometimes } \\
\text { hemispherical }\end{array}$ & nd & nd & $\begin{array}{c}\text { Boukhelkhal and } \\
\text { Moulai-Mostefa [20] }\end{array}$ \\
\hline Quercus branti & 7.32 & SEM & Elliptical and spherical & $\mathrm{C}$ & 47.8 & $\begin{array}{c}\text { Molavi and Razavi } \\
\text { [38] }\end{array}$ \\
\hline Quercus glandulifera Bl. & $3.3-126.2$ & SEM & $\begin{array}{l}\text { Round, triangle, and } \\
\text { elliptical }\end{array}$ & A & 23.53 & Li et al. [7] \\
\hline $\begin{array}{l}\text { Quercus palustris } \\
\text { Muenchh. }\end{array}$ & $3-17$ & SEM & Spherical and ovoid & $\mathrm{A}$ & 22.3 & Stevenson et al. [28] \\
\hline Not specified & $4.8-15.9$ & SEM & Elliptical and spherical & $\mathrm{B}$ & 24.81 & Deng et al. [26] \\
\hline Not specified & nd & SEM & Spherical & A & nd & Chen et al. [27] \\
\hline $\begin{array}{l}\text { Quercus } \\
\text { leucotrichophora }\end{array}$ & $20.6-59$ & SEM & Elliptical & nd & nd & Soni et al. [23] \\
\hline Quercus ilex & nd & nd & nd & $\mathrm{A} / \mathrm{B}$ & nd & Zarroug et al. [21] \\
\hline
\end{tabular}

compounds, and proteins) $[41,44]$. The pasting properties of starch are also influenced by hydrothermal treatments [25]. The pasting properties of acorn starches have been compared with other starches $[26,28,29]$. The peak viscosity of acorn starch was higher than that of buckwheat, coix seed, black wheat kuzhu, longya lily, and naked oat starches and lower than that of jiaoyu and longya lily starches [26].The pasting temperature of acorn starch was higher than that of potato but considerably lower than that of corn, rice, and wheat starches [28].

\section{Swelling and Solubility Index}

When starch is heated in excessive amount of water, its crystalline structure is disrupted, and water molecules become linked by hydrogen bonding to the exposed hydroxyl groups of 
TABLE 3: Gelatinization properties of acorn starch.

\begin{tabular}{|c|c|c|c|c|c|c|c|}
\hline Acorn starch & $\begin{array}{c}\text { Isolation } \\
\text { method }\end{array}$ & $\begin{array}{l}\text { Scanning rate }\left({ }^{\circ} \mathrm{C} /\right. \\
\text { min })\end{array}$ & To $\left({ }^{\circ} \mathrm{C}\right)$ & $\begin{array}{l}\mathrm{Tp} \\
\left({ }^{\circ} \mathrm{C}\right)\end{array}$ & $\begin{array}{l}\mathrm{Tc} \\
\left({ }^{\circ} \mathrm{C}\right)\end{array}$ & $\begin{array}{l}\Delta H(\mathrm{~J} / \\
\mathrm{g})\end{array}$ & Reference \\
\hline \multirow{4}{*}{$\begin{array}{l}\text { Quercus ilex subsp. ballota (four } \\
\text { varieties) }\end{array}$} & \multirow{4}{*}{-} & \multirow{4}{*}{10} & 75.1 & 85.6 & 120 & 15.46 & \multirow{4}{*}{$\begin{array}{c}\text { Boukhelkhal and Moulai- } \\
\text { Mostefa [20] }\end{array}$} \\
\hline & & & 74.8 & 88.1 & 118.9 & 14.31 & \\
\hline & & & 71.3 & 84 & 112.3 & 14.96 & \\
\hline & & & 61 & 71 & 98 & 11.8 & \\
\hline Quercus branti & - & 10 & 59.92 & 71.28 & 80.61 & 14.85 & Molavi et al. [25] \\
\hline Quercus palustris Muenchh. & - & 10 & 65.0 & 73.7 & $\mathrm{Nd}$ & 20.8 & Stevenson et al. [28] \\
\hline Quercus glandulifera $\mathrm{Bl}$. & - & 5 & 60.78 & 66.53 & 73.75 & 4.31 & Li et al. [7] \\
\hline \multirow{4}{*}{ Quercus fabri Hance } & HWS & \multirow{4}{*}{10} & 60.49 & 63.77 & 70.20 & 10.91 & \multirow{4}{*}{ Zhang et al. [33] } \\
\hline & ALW & & 59.52 & 62.88 & 70.93 & 11.38 & \\
\hline & UAES & & 55.34 & 59.52 & 66.64 & 10.45 & \\
\hline & UAWS & & 53.85 & 58.70 & 66.51 & 10.22 & \\
\hline \multirow{2}{*}{ Quercus rotundifolia } & A3S & \multirow{4}{*}{10} & 60.9 & 66.7 & 74.7 & 4.2 & \multirow{4}{*}{ Correia et al. [19] } \\
\hline & ENZ & & 58.7 & 65.7 & 74 & 4.3 & \\
\hline \multirow{2}{*}{ Quercus suber } & $\mathrm{A} 3 \mathrm{~S}$ & & 58.4 & 64.8 & 73.3 & 4.2 & \\
\hline & ENZ & & 58.6 & 64.1 & 71.7 & 4.3 & \\
\hline Quercus leucotrichophora & & 1.5 & $80-85^{\circ} \mathrm{C}$ & nd & $\mathrm{Nd}$ & nd & Soni et al. [23] \\
\hline
\end{tabular}

To: onset gelatinization temperature, Tp: peak gelatinization temperature, Tc: conclusion gelatinization temperature, and $\Delta H$ : enthalpy of gelatinization; isolation method: A3S, alkaline pH using successively three sieves; ENZ, enzymatic method; HWS, hot-water soaking; ALW, alkaline washing; UAES, ultrasonic-assisted ethanol soaking; UAWS, ultrasonic assisted hot-water soaking.

TABLE 4: Pasting properties of acorn starch.

\begin{tabular}{|c|c|c|c|c|c|c|c|c|c|}
\hline \multirow[b]{2}{*}{ Starch } & \multirow[b]{2}{*}{ Instrument } & \multirow[b]{2}{*}{$\begin{array}{l}\text { Isolation } \\
\text { method }\end{array}$} & \multirow[b]{2}{*}{$\begin{array}{c}\text { Pasting } \\
\text { temperature } \\
\left({ }^{\circ} \mathrm{C}\right)\end{array}$} & \multicolumn{3}{|c|}{ Pasting parameter } & \multirow[b]{2}{*}{$\begin{array}{l}\text { Setback } \\
\text { viscosity }\end{array}$} & \multirow[b]{2}{*}{$\begin{array}{c}\text { Final } \\
\text { viscosity }\end{array}$} & \multirow[b]{2}{*}{ Reference } \\
\hline & & & & $\begin{array}{c}\text { Peak } \\
\text { viscosity }\end{array}$ & $\begin{array}{l}\text { Breakdown } \\
\text { viscosity }\end{array}$ & $\begin{array}{c}\text { Trough } \\
\text { viscosity }\end{array}$ & & & \\
\hline Not specified & RVA & - & 82.30 & 3338 & 427 & 2910 & 743 & 3654 & ${ }^{\mathrm{a}}$ Deng et al. [26] \\
\hline Quercus branti & RVA & - & 78.38 & 414.92 & 142.88 & 272.04 & 167.58 & 439.63 & $\begin{array}{c}{ }^{\mathrm{a}} \text { Molavi et al. } \\
{[25]}\end{array}$ \\
\hline $\begin{array}{l}\text { Quercus } \\
\text { palustris } \\
\text { Muenchh. }\end{array}$ & RVA & - & 71.5 & 2196 & 732 & 1464 & 1656 & 3120 & $\begin{array}{c}\text { a Stevenson et al. } \\
{[28]}\end{array}$ \\
\hline $\begin{array}{l}\text { Quercus fabri } \\
\text { Hance }\end{array}$ & RVA & $\begin{array}{l}\text { HWS } \\
\text { ALW } \\
\text { UAES } \\
\text { UAWS }\end{array}$ & $\begin{array}{l}95.30 \\
94.82 \\
86.85 \\
87.15\end{array}$ & $\begin{array}{c}966 \\
485 \\
1037 \\
1032 \\
\end{array}$ & $\begin{array}{c}41.0 \\
124 \\
70.5 \\
54 \\
\end{array}$ & $\begin{array}{l}925 \\
361 \\
967 \\
978\end{array}$ & $\begin{array}{c}164 \\
371.5 \\
324 \\
187 \\
\end{array}$ & $\begin{array}{c}1089 \\
732 \\
1291 \\
1265 \\
\end{array}$ & $\begin{array}{c}\text { a Zhang et al. } \\
{[33]}\end{array}$ \\
\hline $\begin{array}{l}\text { Quercus } \\
\text { rotundifolia }\end{array}$ & & $\begin{array}{l}\text { A3S } \\
\text { ENZ } \\
\text { A3S }\end{array}$ & $\begin{array}{c}70.5 \\
67.5 \\
72\end{array}$ & - & - & - & $\begin{array}{l}1180 \\
1155 \\
1300\end{array}$ & $\begin{array}{l}2575 \\
2453 \\
2540\end{array}$ & ${ }^{\mathrm{b}}$ Correia and \\
\hline Quercus suber & BVA & ENZ & 70.3 & - & - & - & 1630 & 2750 & $\begin{array}{l}\text { Beirão-da- } \\
\text { Costa [32] }\end{array}$ \\
\hline
\end{tabular}

${ }^{a}$ Units measured in rapid viscoanalyzer unit (RVA); ${ }^{b}$ units measured in Brabdender unit (BU); isolation method: A3S, alkaline pH using successively three sieves; ENZ, enzymatic method; HWS, hot-water soaking; ALW, alkaline washing; UAES, ultrasonic-assisted ethanol soaking; UAWS, ultrasonic-assisted hot-water soaking.

amylose and amylopectin, which results in the swelling and solubility of starch granule [46]. The swelling of granules can be measured by swelling power (SP) or swelling factor (SF), while the granular solubilization is described by solubility (\%) (S). SF measures only intragranular water. By contrast, SP measures both inter- and intragranular water [47]. Diversity in swelling and solubility of acorn starch has been observed. For example, evaluation of solubility and swelling at temperature $90^{\circ} \mathrm{C}$ of acorn starches (four varieties) ranged from 4 to $14 \%$ and 11 to $13 \mathrm{~g} / \mathrm{g}$, respectively [20]. Starch isolation method may have effect on property (SP) and solubility of starch. Acorn starch isolated using the ultrasonic-assisted ethanol soaking (UAES) showed a relatively higher value swelling power and solubility compared with other methods; they were about $24.99 \mathrm{~g} / 100 \mathrm{~g}$ and $15.22 \%$, respectively, at temperature $90^{\circ} \mathrm{C}$ [33]. Acorn starch has a low swelling power when compared to potato starch. This may be due to different factors. For example, the high phosphate monoester content in potato starch has been reported to contribute significantly to greater hydration and swelling of potato starch granules [41]. A comparative study showed that swelling power and solubility of acorn starch at $90^{\circ} \mathrm{C}$ were higher than those of black wheat, buckwheat, coix, 
and naked oat starches and lower than those of corn, jiaoyu, kuzhu, and longya lily starches [26]. Factors including amylose content, granule size, structure of starch granules, viscosity patterns, and presence of nonstarch compounds (e.g., lipids and proteins) contributed to their differences $[45,46,51]$.

\section{In Vitro Digestibility}

Starch can be conveniently divided into three categories from a digestibility standpoint, depending on its propensity to be hydrolyzed during intestinal transit through digestive enzymes. These are rapidly digestible starch (RDS, hydrolyzed within $20 \mathrm{~min}$ ), slowly digestible starch (SDS, hydrolyzed between 20 and $120 \mathrm{~min}$ ), and resistant starch (RS, not hydrolyzed within $120 \mathrm{~min}$ ) $[47,49]$. The variation in the digestibility of native starches among and within species has been ascribed to the interplay of many factors such as degree of crystallinity, starch source, amylose-lipid complexes, amylose content, crystallinity, type of crystalline polymorphic (A, B, or C) form, amylose chain length, starch granule size, and amylose/amylopectin ratio [45, 46]. Diversity in resistant starch (RS) content of acorns has been observed (30.8-41.4\%), and the RS content was correlated strongly to isolation method [19]. Furthermore, Lin et al. [50] reported that hydrolysable tannins could be the main active compounds responsible for decreasing acorn digestibility. The high amount of RS in acorn starch indicates the potential of the acorns for preparation of low glycemic index foods.

\section{Modifications and Uses of Starch}

Native starch is usually modified to improve functionality and use in the industry [41]. Starch modification may be achieved by physical, enzymatic, genetic, and chemical methods or through a combination of these methods [39, 41]. Physical starch modification methods including annealing and heat moisture treatment (HMT) are considered safe compared to chemical methods. HMT increased starch solubility, gelatinization temperatures, gelatinization enthalpy, peak time, and pasting temperature, making the starch more resistant against destructive conditions such as long heating or acidic conditions. But these changes were lower on ANN [25]. The modification in the physiochemical properties of pulse starches following hydrothermal treatment has been attributed to interplay of several factors including increased interactions between starch chains, amylose content, formation of amylose lipid complexes, and arrangement of amylose within the amorphous domains of starch [45]. Hydrothermal modifications reduced the viscosity of native acorn starch as follows: HMT $>$ HMTANN $>$ ANN-HMT $>$ ANN. [38]. Galactomannans (guar and locust bean gum) increased the transition temperatures (To, Tp, and Tc) and decreased the gelatinization enthalpy (DH) [51]. The use of different hydrocolloids (Arabic gum, carrageenan, carboxymethyl cellulose, and xanthan gum) to improve the functionality of acorn starch has also been reported [52]. According to this study, the addition of hydrocolloids significantly increased the flow behavior indices, consistency coefficient, gel strength, and pasting properties.
Zheng et al. [18] reported that acorn starch (AS) could improve the mechanical and barrier properties of chitosan$(\mathrm{CH}-)$ based film, and the incorporation of eugenol $(\mathrm{Eu})$ in the film significantly improved the flexibility, barrier, hydrophobicity, and antimicrobial and antioxidant properties. The optimized conditions for film preparation were obtained when the mass ratio of AS to $\mathrm{CH}$ was 0.9 and the content of $\mathrm{Eu}$ was $9 \%$ [18]. Furthermore, $\mathrm{Li}$ et al. [53] reported that glycerol-based acorn nutlet/polycaprolactone composites had superior tensile properties and biodegradable properties, sufficient to partially replace the conventional thermoplastic plastics. It was also reported that the composites prepared with acorn powder and PLA had excellent mechanical and thermal properties [54]. These authors reported also that the hygroscopicity, mechanical properties, and melt flow property of composites were promising even though the composites had a $70 \mathrm{wt} \%$ content of acorn powder.

Bioethanol production from sugar-based feedstocks promises to be a good replacement of fossil fuel, providing the opportunities for a cleaner and low carbon biofuel [55]. Acorn starch was used as a novel feedstock for direct production bioethanol $[56,57]$. Very high gravity (VHG) fermentation technology was conducted to achieve a high ethanol concentration at $86.4 \mathrm{~g} / \mathrm{L}$ [56]. Acorn starch could be also used as a new raw material for $\mathrm{L}(+)$-lactic acid production [54], citric acid [31], and production of hydroxymethylfurfural (HMF) [58].

So far, there have been rather limited studies on the modifications and applications of acorn starch even at the laboratory level. This is probably due to abundant and cheap supply of other starches such as maize, potato, and cassava. Another reason is the limited exploitation of acorn starch for various possible applications. The unique structures and properties of acorn starch may provide potential for diverse applications in some food and nonfood sectors. Comparative studies employing both the acorn starch and common starches (e.g., maize, cassava, and potato) for specific applications (e.g., polymer composite and thermoplastics) should be conducted.

\section{Conclusions and Future Perspectives}

Acorns are underutilized and represent a good alternative source of starch. The conclusions on acorn starch according to the majority of literature are the following: (1) starch yield is up to $55 \%$; (2) amylose content ranges from 15 to $39 \%$; (3) starch granules are most spherical and the size range of $2-24 \mu \mathrm{m}$ was the most frequent; (4) polymorph of acorn starch has been reported mostly as A- and C-type with some reports as B- type; (5) peak gelatinization temperature measured by DSC ranges from $\sim 60$ to $80^{\circ} \mathrm{C}$; and (6) native acorn starch has been used in production of bioethanol, citric acid, and hydroxymethylfurfural (HMF) as well as on biofilm production. Furthermore, acorn starch has potentials for preparation of low glycemic index foods, due to its high levels of RS.

In order to better utilize acorn starches, the following points should be addressed: (1) investigations into methods for increasing the yield and purity of acorn starches should 
be conducted; (2) more genetic resources could be assessed to discover genotypes with novel properties; (3) physicochemical properties of starch such as rheology, retrogradation, gelling, and freeze-thaw stability are to be further characterized; (4) the nonstarch contents (such as phosphorus, lipids, and proteins) of acorn starch should be studied; (5) chemical and molecular structures of amylose and amylopectin should be further studied; (6) the internal molecular structure of acorn starches in relation to physicochemical properties is to be studied; (7) comparative studies employing other starch (e.g., cassava, maize, and potato) as reference should be conducted to explore if there is any advantage of using acorn starches; (8) chemical, physical, and enzymatic modifications or their dual/triple combinations could be applied on acorn starch in the future; and (9) further research on acorn starch should be explored using advanced technologies such as nuclear magnetic resonance, atomic strength microscopy, and other improved characterization techniques.

\section{Data Availability}

The data used to support the findings of this study are available from the corresponding author upon request.

\section{Conflicts of Interest}

The authors declare that there are no conflicts of interest.

\section{References}

[1] Y. R. Tantray, M. S. Wani, and A. Hussain, "Genus Quercus: an overview," International Journal of Advanced Research in Science, Engineering and Technology, vol. 6, pp. 1880-1886, 2017.

[2] A. F. Vinha, J. C. M. Barreira, A. S. G. Costa, and M. B. P. P. Oliveira, “A new age for Quercus spp. fruits: review on nutritional and phytochemical composition and related biological activities of acorns," Comprehensive Reviews in Food Science and Food Safety, vol. 15, no. 6, pp. 947-981, 2016.

[3] M. Taib, L. Bouyazza, and B. Lyoussi, "Acorn oil: chemistry and functionality," Journal of Food Quality, vol. 2020, Article ID 8898370, 11 pages, 2020.

[4] T. Özcan, "Total protein and amino acid compositions in the acorns of Turkish Quercus L. taxa," Genetic Resources and Crop Evolution, vol. 53, no. 2, pp. 419-429, 2006.

[5] T. Özcan, "Characterization of Turkish Quercus L. taxa based on fatty acid compositions of the acorns," Journal of the American Oil Chemists' Society, vol. 84, no. 7, pp. 653-662, 2007.

[6] W. M. Al-Rousan, R. Y. Ajo, K. M. Al-Ismail, A. Attlee, R. R. Shaker, and T. M. Osaili, "Characterization of acorn fruit oils extracted from selected mediterranean Quercus species," Grasas y Aceites, vol. 64, no. 5, pp. 554-560, 2013.

[7] S. Li, Y. Zhou, M. Liu, Y. Zhang, and S. Cao, "Nutrient composition and starch characteristics of Quercus glandulifera Bl. seeds from China," Food Chemistry, vol. 185, pp. 371-376, 2015.

[8] K. Salajpal, D. Karolyi, M. Dikić, V. Kantura, G. Kiš, and Ž. Sinjer, "Influence of acorn intake on blood lipid profile and longisimus muscle characteristics of black slavonian pig," Acta Agriculturae Slovenica, vol. 2, pp. 99-105, 2008.
[9] A. Skendi, P. Mouselemidou, M. Papageorgiou, and E. Papastergiadis, "Effect of acorn meal-water combinations on technological properties and fine structure of gluten-free bread," Food Chemistry, vol. 253, pp. 119-126, 2018.

[10] L. Custódio, J. Patarra, F. Alberício, N. d. R. Neng, J. M. F. Nogueira, and A. Romano, "Phenolic composition, antioxidant potential and in vitro inhibitory activity of leaves and acorns of Quercus suber on key enzymes relevant for hyperglycemia and Alzheimer's disease," Industrial Crops and Products, vol. 64, pp. 45-51, 2015.

[11] E. Cantos, J. C. Espín, C. López-Bote, L. de la Hoz, J. A. Ordóñez, and F. A. Tomás-Barberán, "Phenolic compounds and fatty acids from acorns (Quercus spp.), the main dietary constituent of free-ranged iberian pigs," Journal of Agricultural and Food Chemistry, vol. 51, no. 21, pp. 62486255, 2003.

[12] M. Taib, Y. Rezzak, L. Bouyazza, and B. Lyoussi, "Medicinal uses, phytochemistry, and pharmacological activities of Quercus species," Evidence-Based Complementary and Alternative Medicine, vol. 2020, Article ID 1920683, 20 pages, 2020.

[13] J. H. Jung and H. H. Yoon, "Sensory characteristics and consumer acceptance of gluten-free rice pasta with added buckwheat, mungbean and acorn starches," Korean Journal of Food \& Cookery Science, vol. 32, no. 4, pp. 413-425, 2016.

[14] A. Korus, D. Gumul, M. Krystyjan, L. Juszczak, and J. Korus, "Evaluation of the quality, nutritional value and antioxidant activity of gluten-free biscuits made from corn-acorn flour or corn-hemp flour composites," European Food Research and Technology, vol. 243, no. 8, pp. 1429-1438, 2017.

[15] J. Korus, M. Witczak, R. Ziobro, and L. Juszczak, “The influence of acorn flour on rheological properties of gluten-free dough and physical characteristics of the bread," European Food Research and Technology, vol. 240, no. 6, pp. 1135-1143, 2015.

[16] O. Özünlü, H. Ergezer, and R. Gökçe, "Improving physicochemical, antioxidative and sensory quality of raw chicken meat by using acorn extracts," LWT, vol. 98, pp. 477-484, 2018.

[17] M. P. Pereira and L. Oliveira, "Acorn: a fruit with applications in the food industry," in Proceedings of the XVII Congresso De Nutrição e Alimentação/I Congresso Internacional De Nutrição e Alimentação da APN, Lisbon, Portugal, 2018.

[18] K. Zheng, S. Xiao, W. Li et al., "Chitosan-acorn starch-eugenol edible film: physico-chemical, barrier, antimicrobial, antioxidant and structural properties," International Journal of Biological Macromolecules, vol. 135, pp. 344-352, 2019.

[19] P. R. Correia, M. C. Nunes, and M. L. Beirão-da-Costa, "The effect of starch isolation method on physical and functional properties of Portuguese nut starches. II. Q. rotundifolia lam. and Q. suber lam. acorns starches," Food Hydrocolloids, vol. 30, no. 1, pp. 448-455, 2013.

[20] M. Boukhelkhal and N. Moulai-Mostefa, "Physicochemical characterization of starch isolated from soft acorns of holm oak (Quercus ilex subsp. ballota (desf.) samp.) grown in Algeria," Journal of Food Measurement and Characterization, vol. 11, no. 4, pp. 1995-2005, 2017.

[21] Y. Zarroug, M. Boulares, J. Mejri et al., "Extraction and characterization of Tunisian Quercus ilex starch and its effect on fermented dairy product quality," International Journal of Analytical Chemistry, vol. 2020, Article ID 8868673, 9 pages, 2020.

[22] H. Irinislimane and N. Belhaneche-Bensemra, "Extraction and characterization of starch from oak acorn, sorghum, and 
potato and adsorption application for removal of maxilon red GRL from wastewater," Chemical Engineering Communications, vol. 204, no. 8, pp. 897-906, 2017.

[23] P. L. Soni, H. Sharma, D. Dun, and M. M. Gharia, "Physicochemical properties of Quercus leucotrichophora (oak) starch," Starch-Stärke, vol. 45, no. 4, pp. 127-130, 1993.

[24] S.-H. Yoo, C.-S. Lee, B.-S. Kim, and M. Shin, “The properties and molecular structures of gusiljatbam starch compared to those of acorn and chestnut starches," Starch-Stärke, vol. 64, no. 5, pp. 339-347, 2012.

[25] H. Molavi, S. M. A. Razavi, and R. Farhoosh, "Impact of hydrothermal modifications on the physicochemical, morphology, crystallinity, pasting and thermal properties of acorn starch," Food Chemistry, vol. 245, pp. 385-393, 2018.

[26] M. Deng, C. K. Reddy, and B. Xu, "Morphological, physicochemical, and functional properties of underutilized starches in China," International Journal of Biological Macromolecules, vol. 158, pp. 648-655, 2020.

[27] X. Chen, X. Li, X. Shi, and L. Li, "Analysis on basic physicochemical properties and antioxidant activities of the starch from acorn," Hans Journal of Food and Nutrition Science, vol. 8, no. 3, pp. 195-207, 2019.

[28] D. G. Stevenson, J.-L. Jane, and G. E. Inglett, "Physicochemical properties of pin oak (Quercus palustris muenchh.) acorn starch," Starch-Stärke, vol. 58, no. 11, pp. 553-560, 2006.

[29] P. R. Correia and M. L. Beirão-da-Costa, "Chestnut and acorn starch properties affected by isolation methods," StarchStärke, vol. 62, no. 8, pp. 421-428, 2010.

[30] Y. Lin, Y. Lu, Z. Song, and D. Huang, "Characterizations of the endogenous starch hydrolase inhibitors in acorns of Quercus fabri hance," Food Chemistry, vol. 258, pp. 111-117, 2018.

[31] N. Zhang, J.-C. Jiang, J. Yang et al., "Citric acid production from acorn starch by tannin tolerance mutant Aspergillus niger AA120," Applied Biochemistry and Biotechnology, vol. 188, no. 1, pp. 1-11, 2019.

[32] P. R. Correia and M. L. Beirão-da-Costa, "Starch isolation from chestnut and acorn flours through alkaline and enzymatic methods," Food and Bioproducts Processing, vol. 90, no. 2, pp. 309-316, 2012.

[33] Z. Zhang, A. S. Saleh, H. Wu et al., "Effect of starch isolation method on structural and physicochemical properties of acorn kernel starch," Starch-Stärke, vol. 72, no. 1-2, Article ID 1900122, 2020.

[34] P. R. Correia, A. S. Leitão, M. L. Beirão-da-Costa et al., "Effect of drying temperatures on chemical and morphological properties of acorn flours," International Journal of Food Science \& Technology, vol. 44, no. 9, pp. 1729-1736, 2020.

[35] S. H. Li, J. L. Xia, C. P. Wang et al., "The physical and chemical analysis of carbohydrate content in acorn kernel," Advanced Materials Research, vol. 554-556, pp. 2006-2012, 2012.

[36] I. A. Wani, D. S. Sogi, A. M. Hamdani, A. Gani, N. A. Bhat, and A. Shah, "Isolation, composition, and physicochemical properties of starch from legumes: a review," Starch-Stärke, vol. 68, no. 9-10, pp. 834-845, 2016.

[37] S. M. Chisenga, T. S. Workneh, G. Bultosa, and B. A. Alimi, "Progress in research and applications of cassava flour and starch: a review," Journal of Food Science and Technology, vol. 56, no. 6, pp. 2799-2813, 2019.

[38] H. Molavi and S. M. Razavi, "Steady shear rheological properties of native and hydrothermally modified Persian acorn (Quercus brantii lindle.) starches," Starch-Stärke, vol. 70, no. 3-4, Article ID 1700156, 2018.
[39] F. Zhu, "Composition, structure, physicochemical properties, and modifications of cassava starch," Carbohydrate Polymers, vol. 122, pp. 456-480, 2015.

[40] S. Pérez and E. Bertoft, "The molecular structures of starch components and their contribution to the architecture of starch granules: a comprehensive review," Starch-Stärke, vol. 62, no. 8, pp. 389-420, 2010.

[41] S. A. Oyeyinka and A. T. Oyeyinka, "A review on isolation, composition, physicochemical properties and modification of bambara groundnut starch," Food Hydrocolloids, vol. 75, pp. 62-71, 2018.

[42] J. O. Kim and M. J. Lee, "Studies on some physico-chemical properties of the acorn starch," Korean Journal of Food Science and Technology, vol. 8, no. 4, pp. 230-235, 1976.

[43] Z. Ning, J. Jian-Chun, Y. Jing et al., "Ethanol production from acorn starch by tannin tolerance mutant Pachysolen tannophilus," Energy Sources, Part A: Recovery, Utilization, and Environmental Effects, vol. 40, no. 5, pp. 572-578, 2018.

[44] F. Zhu, "Structures, properties, and applications of lotus starches," Food Hydrocolloids, vol. 63, pp. 332-348, 2017.

[45] R. Hoover, T. Hughes, H. J. Chung, and Q. Liu, "Composition, molecular structure, properties, and modification of pulse starches: a review," Food Research International, vol. 43, no. 2, pp. 399-413, 2010.

[46] T. Vasanthan and R. Hoover, "Barley starch: production, properties, modification and uses," in Starch, pp. 601-628, Academic Press, Cambridge, MA, USA, 2009.

[47] J. H. Dupuis and Q. Liu, "Potato starch: a review of physicochemical, functional and nutritional properties," American Journal of Potato Research, vol. 96, no. 2, pp. 127-138, 2019.

[48] F. Zhu, "Structure, physicochemical properties, and uses of millet starch," Food Research International, vol. 64, pp. 200211, 2014.

[49] H. N. Englyst, S. M. Kingman, and J. H. Cummings, "Classification and measurement of nutritionally important starch fractions," European Journal of Clinical Nutrition, vol. 46, pp. S33-S50, 1992.

[50] Y. Lin, S. M. Lu, Z. Song, and D. Huang, "Characterizations of the endogenous starch hydrolase inhibitors in acorns of Quercus fabri Hance," Food Chemistry, vol. 258, pp. 111-117, 2018.

[51] W. W. Kim and B. Yoo, "Rheological and thermal effects of galactomannan addition to acorn starch paste," LWT-Food Science and Technology, vol. 44, no. 3, pp. 759-764, 2011.

[52] M. Saleh, R. Ajo, K. Al-Ismail, and G. Ondier, "Effects of hydrocolloids on acorn starch physical properties," StarchStärke, vol. 68, no. 11-12, pp. 1169-1179, 2016.

[53] S. Li, C. Wang, F. Chu, J. Xia, and Y. Xu, "New non-foodbased composites of acorn nutlet and polycaprolactone: preparation and characterization evaluation," Journal of Polymers and the Environment, vol. 21, no. 4, pp. 1072-1082, 2013.

[54] Z. Lu, F. He, Y. Shi, M. Lu, and L. Yu, "Fermentative production of $\mathrm{L}(+)$-lactic acid using hydrolyzed acorn starch, persimmon juice and wheat bran hydrolysate as nutrients," Bioresource Technology, vol. 101, no. 10, pp. 3642-3648, 2010.

[55] B. V. Ayodele, M. A. Alsaffar, and S. I. Mustapa, "An overview of integration opportunities for sustainable bioethanol production from first- and second-generation sugar-based feedstocks," Journal of Cleaner Production, vol. 245, Article ID 118857, 2020.

[56] B. Chao, R. Liu, X. Zhang, X. Zhang, and T. Tan, “Tannin extraction pretreatment and very high gravity fermentation of 
acorn starch for bioethanol production," Bioresource Technology, vol. 241, pp. 900-907, 2017.

[57] F. Heidari, M. A. Asadollahi, A. Jeihanipour, M. Kheyrandish, H. Rismani-Yazdi, and K. Karimi, "Biobutanol production using unhydrolyzed waste acorn as a novel substrate," RSC Advances, vol. 6, no. 11, pp. 9254-9260, 2016.

[58] J.-W. Lee, M.-G. Ha, Y.-B. Yi, and C.-H. Chung, "Chromium halides mediated production of hydroxymethylfurfural from starch-rich acorn biomass in an acidic ionic liquid," Carbohydrate Research, vol. 346, no. 2, pp. 177-182, 2011. 